\title{
Capital, império e fotografia: evidências dos álbuns fotográficos de empresas coloniais em Angola e Moçambique durante o scramble for Africa
}

\author{
Capital, empire and photography: evidence from the \\ photo albums of colonial companies in Angola and \\ Mozambique during the scramble for Africa
}

\section{Hugo Silveira Pereira \\ i Investigador auxiliar, Centro Interuniversitário de História das Ciências e da Tecnologia/ Universidade Nova de Lisboa. Almada - Setúbal - Portugal orcid.org/0000-0002-7706-2686 hjs.pereira@fct.unl.pt}

Recebido em 16 mar. 2020. Aprovado em 25 jun. 2020.
PEREIRA, Hugo Silveira. Capital, império e fotografia: evidências dos álbuns fotográficos de empresas coloniais em Angola e Moçambique durante o scramble for Africa. História, Ciências, Saúde-Manguinhos, Rio de Janeiro, v.28, n.4, out.-dez. 2021, p.1137-1157.

\section{Resumo}

Na viragem do século XIX para o XX, Portugal confiou a implementação de sistemas tecnológicos nas suas colónias de Angola e Moçambique a diversas empresas privadas. Essas companhias decidiram preservar para a posteridade as suas atividades por meio da fotografia. Neste artigo, analiso quatro álbuns empresariais de firmas coloniais, combinando uma metodologia semiótica com conceitos de história da tecnologia. Argumento que a fotografia, apesar de publicitada como um instrumento objetivo de registar a realidade, era uma atividade extremamente subjetiva, mas que tomou partido dessa alegada objetividade para criar e fortalecer mitos, pelo impacto da sua visualidade. Contribuo para o debate sobre a importância da cultura visual para estudos coloniais.

Palavras-chave: fotografia; engenharia; história da tecnologia; colonialismo; racismo.

\begin{abstract}
In the late 19th-early 20th century, Portugal entrusted the implementation of technological systems in its colonies in Angola and Mozambique to several private companies. These companies decided to preserve their activities through photography for posterity. In this article, I analyze four business albums from colonial firms, combining a semiotic methodology with concepts from the history of technology. I argue that photography, despite being advertised as an objective instrument to record reality, was extremely subjective, but that it took advantage of this alleged objectivity to create and strengthen myths, through the impact of its visuality. I also contribute to the debate on the importance of visual culture for colonial studies.
\end{abstract}

Keywords: photography; engineering; history of technology; colonialism; racism. 
A partir da década de 1880, na sequência da Conferência de Berlim e do início da "partilha de África", Portugal procurou cimentar a sua presença nas suas colónias de Angola e Moçambique por intermédio de expedições tecnocientíficas, ações militares e construção de grandes obras públicas (Alexandre, 2000, p.182-184). Neste ensaio fotográfico, analiso este último processo histórico da perspetiva de álbuns fotográficos de empresas coloniais intensivas em capital técnico e financeiro, evidenciando as representações sobre a sua própria ação e sobre África.

Parto do princípio de que esses processos foram marcados por fenómenos de acumulação de capital e forte investimento em sistemas tecnológicos (Gilmartin, 2009, p.115; Headrick, 1981, p.5-11), numa época em que ciência e tecnologia eram as bitolas pelas quais se media o valor das diferentes nações (Adas, 1989, p.134), o que contribuiu para uma retórica que conferia aos países europeus o dever de "civilizar" os africanos (Jerónimo, 2015). Argumento que as grandes obras de engenharia (ferrovias e não só) funcionaram como hotspots de imperialismo, onde as desigualdades de riqueza e poder eram evidentes e desembocaram em relações de dominação e discriminação.

Esses processos foram acompanhados de perto pela fotografia, que na viragem de Oitocentos para Novecentos se tornara uma atividade comum, graças à simplificação dos processos fotográficos (Freund, 1995, p.37-43). Como produto da ciência e da tecnologia, a fotografia foi revestida duma alegada objetividade que os desenhos e pinturas não tinham (Ryan, 1997, p.17). Juntamente com outras tecnologias coevas, a fotografia tornou-se um dos instrumentos mais insidiosos de espacialização social de finais do século XIX e inícios do século XX (Foster, 2003, p.141).

Neste ensaio, recorro a uma metodologia que combina semiótica com estudos de história da tecnologia para analisar 276 imagens de seis álbuns fotográficos editados entre 1887 e 1934 por quatro empresas coloniais que laboraram no espaço ultramarino português. São companhias que reuniram uma substancial massa de capital para implementar grandes obras públicas e sistemas tecnológicos típicos do "novo imperialismo". Quase todas se envolveram numa modalidade especialmente intrusiva de imperialismo, usualmente associada à "missão civilizadora": o imperialismo ferroviário, isto é, o uso da ferrovia (e do capital, expertise e indústria a ela associados) para controlar territórios e recursos estrangeiros, cujos benefícios recaíam quase exclusivamente sobre os seus promotores, com poucos ganhos para as populações locais (Davis, Wilburn, Robinson, 1991). Duas daquelas empresas foram geridas por portugueses (ainda que financiadas por capital britânico), enquanto as demais foram inteiramente dominadas por agentes ingleses, o que fornece uma perspetiva dupla (nacional e estrangeira) sobre o investimento europeu nos domínios ultramarinos portugueses. Foco-me sobretudo nas fotografias geradas nesse contexto, não contemplando a análise de material documental escrito a elas associado, mas tendo em conta todo o contexto ideológico, político e económico da época. Ainda que com essa limitação, este trabalho contribui para o debate que realça a importância da visualidade da ciência e da tecnologia nos processos coloniais do "novo imperialismo" de finais do século XIX e inícios do século XX (Vicente, 2014, p.12-18). 


\section{Fontes e seu uso}

As fotografias selecionadas são do período entre 1887 e 1911, cobrindo, portanto, um período crítico do "novo imperialismo" português. Incluem imagens de atividades de quatro empresas que laboraram na África portuguesa: em Angola, a Companhia Real dos Caminhos de Ferro Através d'África e a Companhia do Caminho de Ferro de Benguela (164 imagens); em Moçambique, a Delagoa Bay \& East African Railway Company e a Companhia de Moçambique (112 fotografias - ver Tabela 1). Todas foram firmas ferroviárias, à exceção da Companhia de Moçambique, que foi uma empresa (fundada em 1891) titular de poderes majestáticos sobre os territórios de Manica e Sofala. ${ }^{1}$

Tabela 1: Panorâmica da amostra de imagens selecionadas

\begin{tabular}{lllr}
\hline \multirow{2}{*}{ Empresa } & Fonte & Datas & Quantidade de fotos \\
\hline \multirow{2}{*}{ Companhia Através d'África } & Miscelânea..., c.1894 & c.1895 & $28^{*}$ \\
\cline { 2 - 4 } & Memória..., 1909 & c.1895-c.1909 & 42 \\
\hline \multirow{2}{*}{ Delagoa Bay Company } & Benguela Railway, c.1906 & $1904-1906$ & 94 \\
\hline \multirow{2}{*}{ Companhia de Moçambique } & & Total Angola & 164 \\
\hline & Views..., c.1887 & c.1887 & 71 \\
\cline { 2 - 4 } & Território..., 1902 & c.1892-c.1902 & $19^{* *}$ \\
\hline & & $1888-1911$ & 22 \\
\hline
\end{tabular}

* Contém 18 fotos replicadas em Memória... (1909).

** Contém uma foto repetida em Quarenta... (1934).

Fonte: elaborada pelo autor com base nas fontes indicadas na tabela.

Essas imagens eram tidas como completamente objetivas, retratando a realidade tal como ela era, mas, na verdade, eram um documento eminentemente subjetivo, que resultava do contexto da época e dum conjunto de escolhas do fotógrafo (assunto, ângulo, pose), que pretendia atingir determinados objetivos (Dubois, 1992, p.45). Porém, do ponto de vista do investigador, importa não ceder à tentação de ver constantemente significados escondidos em toda a imagem fotográfica (Heintze, 1990, p.147). Necessário é seguir um conjunto de princípios metodológicos para analisar uma amostra fotográfica.

A esse propósito, Barthes (1972, p.109-156) sugere a identificação de três elementos distintos numa imagem fotográfica: o significante (o retratado), o significado (a mensagem transmitida) e o signo (o mito gerado). Para a determinação desses três elementos, importa considerar três outros fatores: o autor da foto, a sua audiência provável e a legenda. A identidade do fotógrafo pode antecipar uma determinada intenção na foto. No caso em análise, os fotógrafos não são conhecidos, embora se aceite que os criadores dos álbuns foram as companhias indicadas. A mensagem a transmitir depende do público a quem as fotos são dirigidas (Flick, 2003, p.391). Os álbuns seriam destinados aos investidores das empresas (Oliveira, 2018, p.703) e eventualmente a figuras políticas, mas também à imprensa ilustrada, que poderia ter interesse nas fotografias. Por essa altura, o periodismo 
ilustrado português (recorrendo à xilogravura e ao halftone) conhecia um considerável desenvolvimento (Sousa, 2017, p.575-576) e algumas das imagens foram publicadas, sobretudo n'O Ocidente e na Ilustração Portuguesa (Martins, 2014). Por fim, a legenda assume uma especial importância, pois orienta imediatamente a atenção do observador num determinado sentido, que se pretende valorar (Franklin, Becklen, Doyle, 1993). Todas as fotos analisadas estão legendadas, à exceção das constantes em Views... (c.1887).

Em estudos de fotografia, outra importante componente da análise é o conjunto de documentação escrita associada aos agentes produtores ou retratados nas imagens fotográficas, considerando que a cultura visual não deve ser dissociada da cultura escrita/ material que de algum modo a explica (Vicente, 2014, p.12). Tendo em conta, porém, a natureza de ensaio fotográfico deste trabalho, privilegio a análise de fotografias, colocandoas em confronto com o conhecimento historiográfico da época. Naturalmente, nessas condições, as interpretações e conclusões apresentadas não podem ser consideradas definitivas, mas permitem olhar para o processo colonial português a partir de outra perspetiva documental.

Em termos práticos, o corpus documental foi dividido em grupos com características semelhantes, em consonância com o significante das fotos, que permitem realçar certos significados. Nessa divisão, foi também considerada a repetição de significantes, que contribui para a criação de significados e mitos mais compreensíveis (Beegan, 2008, p.23).

\section{Fotografar para registar}

Anteriormente, referi que a fotografia pode ter uma função utilitarista, além de simbólica. A esse respeito, importa realçar que os álbuns analisados são um tipo de produção editorial muito comum na época: o álbum empresarial, encomendado por companhias privadas (para uma lista de álbuns de empresas ferroviárias, ver Oliveira, 2018, p.696-697). Em Portugal, a publicação de álbuns empresariais (sobretudo no setor da via-férrea) tinha igualmente alguma tradição, destacando-se as coleções das linhas do Tua, Beira Alta e Salamanca, publicadas na década de 1880. Essas imagens respondiam em grande medida a quesitos técnicos, para registar fielmente a natureza do terreno, a evolução e integridade das obras e o funcionamento de certos maquinismos. A câmara tornava-se um instrumento de trabalho dos engenheiros (Oliveira, 2018, p.701-702, 704-705). Assim que as imagens eram integradas num álbum, contudo, perdiam um pouco daquela funcionalidade e destinavam-se a publicitar os esforços das companhias junto dos seus investidores e dos poderes públicos, assegurando a boa aplicação do capital investido. Para os efeitos deste artigo, é importante referir que em Portugal havia uma substancial desconfiança contra empreendimentos privados nas colónias, devido a uns escândalos financeiros e à crescente influência de agentes estrangeiros (Navarro, 2018). Fotografias retratando o avançar da obra pública poderiam ter o efeito de contrariar aquela opinião negativa, sobretudo se encontrassem respaldo (como encontraram) na imprensa da época. A esse respeito, o caso da Companhia Através d'África é particularmente ilustrativo, uma vez que absorvia muitos subsídios públicos sem contribuir visivelmente para a colonização de Angola (Navarro, 2018, p.244-251). A firma culpava o governo, e no relatório que editou (Memória..., 1909) 
recorreu profusamente à fotografia para suportar a sua argumentação. Além dessa categoria, os álbuns analisados neste artigo também podem ser incluídos numa outra tipologia igualmente característica da época, de vocação vincadamente mais propagandística: o álbum colonial, destinado a ilustrar os domínios ultramarinos portugueses, mostrar a presença militar lusa, o exotismo e primitivismo, mas também a habitabilidade de África e o sucesso e bonomia da colonização daqueles territórios (Fernandes, 2014, p.205-208; Rocha, Matos, 2019). Assim, os álbuns das companhias identificadas na Tabela 1 conferem à construção visual da colonização portuguesa de África uma forte componente política, além de meramente utilitarista ou empresarial.

\section{Mensageiros de "progresso"}

O significante mais evidente nas fotos é o de "progresso" baseado no desenvolvimento tecnocientífico, suportado por fluxos de capital financeiro e aplicado à dominação colonial. Ao todo, existem 156 fotografias (mais de metade da amostra) nas quais o significante predominante (quer na foto, quer na legenda) são aspetos de implementação tecnológica (Tabela 2), incluindo linhas férreas (convencionais e tramways), comboios e locomotivas, obras de engenharia (pontes, trincheiras e viadutos), estações e outras infraestruturas ferroviárias, portos, arruamentos, edifícios públicos e empreendimentos comerciais e industriais.

Tabela 2: Análise da amostra fotográfica por categoria classificativa

\begin{tabular}{lccccccccc}
\hline & \multicolumn{10}{c}{ Categoria } \\
\cline { 2 - 10 } Álbum & \multicolumn{1}{c}{ Progresso } & \multicolumn{1}{c}{ Engenheiros } & Exotismo africano & Negros, outros \\
\cline { 2 - 10 } & Núm. & $\begin{array}{l}\text { \% do } \\
\text { álbum }\end{array}$ & Núm. & $\begin{array}{l}\text { \% do } \\
\text { álbum }\end{array}$ & Núm. & $\begin{array}{l}\text { \% do } \\
\text { álbum }\end{array}$ & Núm. & $\begin{array}{l}\text { \% do } \\
\text { álbum }\end{array}$ \\
\hline Companhia Através d'África & 47 & 67,1 & 32 & 45,7 & 24 & 34,3 & 10 & 14,3 \\
\hline Companhia de Moçambique & 38 & 92,7 & 8 & 19,5 & 4 & 9,8 & 10 & 24,4 \\
\hline Companhia de Benguela & 44 & 46,8 & 20 & 21,3 & 20 & 21,3 & 15 & 16 \\
\hline Delagoa Bay Company & 27 & 38 & 30 & 42,3 & 12 & 16,9 & 30 & 42,3 \\
\hline Totais & 156 & 56,5 & 90 & 32,6 & 60 & 21,7 & 65 & 23,6
\end{tabular}

Fonte: elaborada pelo autor com base nas fontes indicadas na Tabela 1.

Foram as empresas geridas por portugueses que mais apostaram nesse tipo de imagens, demonstrando a sua preocupação em ilustrar o seu papel de fomentadores do "progresso" e da colonização e aproveitamento económico dos territórios. As firmas estrangeiras privilegiavam outro tipo de cenário. Estas e aquelas contribuíam para uma cultura visual de desenvolvimento tecnocientífico para tentar contrariar a representação partilhada por outras nações imperiais de que Portugal era uma nação incapaz de colonizar África e que não deveria ter colónias. No ideário nacional, os domínios ultramarinos representavam provas do passado glorioso dos descobrimentos e uma promessa de recuperação económica 
da nação (respetivamente, mitos da herança sagrada e do El Dorado, segundo Alexandre, 2000). Por meio do "progresso" divulgado pela fotografia, procurava-se afastar essa perceção de desleixo para demonstrar a soberania portuguesa sobre Angola e Moçambique e a capacidade nacional para explorar seus territórios.

Com a fotografia, retratava-se o sublime técnico da locomotiva (Figura 1), ${ }^{2}$ a imponência duma estação (Figura 2) ou o efeito úbere da ferrovia na implementação de novos povoados, oficinas e fábricas ao longo do percurso. Em Benguela Railway (c.1906), vinca-se um elemento intrínseco ao "progresso", ao capitalismo industrial e aos projetos imperiais da época: o aço. Em 17 imagens (18\% do álbum), são retratadas apenas peças de pontes e viadutos. Nada mais se destaca, exceto a rigidez de linhas e clareza das estruturas metálicas. Os álbuns da Companhia de Moçambique alargam a tipologia dessas intervenções imperiais na paisagem colonial, com retratos de projetos urbanos (as ruas na cidade da Beira, o crescimento da frente construída, os sistemas de transporte público urbano) e hidráulicos/portuários (os melhoramentos no porto da Beira - Figuras 3 e 4). Esses álbuns mostram a antropogenização da paisagem duma forma particularmente eficaz, com sequências de imagens do porto e da cidade da Beira em anos sucessivos, ilustrando a notável evolução daqueles espaços.

Em suma, documentava-se a europeização do território, o fomento duma mobilidade facilitada (comum na Europa), bem como a eficácia das ligações transoceânicas e suas promessas de globalização. À fotografia, pedia-se emprestada a sua alegada objetividade para transmitir objetivamente a subjetividade do "progresso".

\section{Agentes de modernidade}

Na realização do "progresso", um agente desempenhou um papel crucial: os engenheiros, que detinham os conhecimentos técnicos para implementar os grandes sistemas tecnológicos e que tiveram na fotografia uma aliada.

A fotografia realçou o valor desses agentes (e seus auxiliares técnicos) em diversos contextos e de diversos modos (Matos, 2014, p.12). Por meio dos álbuns analisados neste artigo, as companhias coloniais reconheceram igualmente os méritos dos seus staffs técnicos (engenheiros, auxiliares, condutores etc.), ${ }^{3}$ ainda que não lhes tenham conferido tanta importância como à tecnologia propriamente dita. No total, existem noventa fotos (cerca de 1/3 da amostra) onde se identifica claramente pessoal técnico (Tabela 2). A Companhia de Moçambique constitui exceção, praticamente não retratando nenhum daqueles agentes tecnocráticos, o que se deve ao fato de muitas das obras terem sido feitas por subconcessionárias britânicas com quem a majestática portuguesa manteve relações algo tensas (Navarro, 2018, p.330-342).

A tipologia iconográfica mais simples era a que apresentava grupos de engenheiros posando para a objetiva em acampamentos de construção, nos estaleiros de obra ou dentro de edifícios da direção (Figura 5). O objetivo parece ter sido meramente ilustrativo, no sentido de preservar para a posteridade as faces dos responsáveis técnicos pelo "progresso", ainda que em termos identificativos nem fotos nem legendas nomeiem os retratados.

Bem mais significativas do ponto de vista simbólico são as imagens que retratam engenheiros e seus subordinados em ação: conduzindo ou empoleirados em locomotivas 
(Figura 1), vogando pela ferrovia ou perfilando-se com obras de engenharia (Figuras 6, 7 e 10). ${ }^{4}$ Os significantes variam conforme o sistema ou artefacto tecnológico fotografado, mas todos apontam para um mesmo conjunto de significados: aquelas obras existem graças à ação dos engenheiros, que, com a sua perícia e conhecimento, transformaram a ideia, o capital e o aço em instrumentos de desenvolvimento, mobilidade e império. O ângulo e a composição da imagem reforçavam essa mensagem. Em algumas ocasiões (Figura 6), a posição dos engenheiros em face das obras de engenharia servia de escala para vincar a dimensão destas últimas e a exigência da sua construção (Oliveira, 2018, p.705). Noutras instâncias, o técnico deixava-se fotografar perfilado pelos caprichos da natureza (Figura 7). Duas mensagens eram transmitidas desse modo, consoante a foto incluísse ou não a tecnologia. No segundo caso, empolava-se a paisagem implacável de África, com densas selvas ou profundas ravinas, que iriam exigir o máximo da coragem e génio do engenheiro para ali impor o "progresso"; no primeiro caso, o complexo técnico trazido pela mão do engenheiro impunha-se à envolvente geográfica, "domesticava" África (Diogo, 2009) e abria-a às incursões coloniais do europeu. Este último efeito era avivado pelo contraste entre a rigidez das linhas férreas e a "desordem" da paisagem africana (cf. Fortier-Kriegel, 2005, p.93, 98).

A promoção da figura dos engenheiros como agentes de "progresso" fazia-se também no momento das inaugurações. Essas cerimónias representavam não só o fim bem-sucedido dum processo de implementação técnica, mas também atos simbólicos que agregavam os seus participantes para anunciar o futuro e a modernidade (Nye, 1999, p.65). Naturalmente, os engenheiros não podiam deixar de estar presentes e num lugar de destaque. As poucas imagens disponíveis desses momentos confirmam precisamente isso, mostrando-os em cima das locomotivas e por cima de todos os outros, incluindo o poder clerical, o poder administrativo e, como seria de esperar, os nativos, assim demonstrando a predominância da sua agência (Figura 8).

\section{Propaganda de África}

Assim que completas as obras, as companhias coloniais tinham de captar colonos e negócios para utilizarem as novas infraestruturas. Todavia, a atração que África exercia sobre os portugueses na metrópole era reduzida (as colónias eram consideradas terra de desterro e morte). Os números da emigração e do comércio foram sempre muito modestos até meados do século XX (Lains, 1998, p.467). Daí que os álbuns também procuraram promover os domínios ultramarinos como destino para viver, trabalhar e procurar um futuro melhor.

Essa publicitação do continente africano fazia-se de dois modos. O primeiro passava por exibir o exotismo da paisagem africana, insinuando a potencialidade económica daqueles territórios (Martins, 2014, p.94, 97). Nos álbuns, encontram-se sessenta imagens que ilustram selvas luxuriantes, rios caudalosos ou altas montanhas (Tabela 2 e Figuras 9 a 12). Esse número é relativamente reduzido (cerca de $21 \%$ do total de fotografias), sobretudo em comparação com as gravuras de itens tecnocientíficos. O romanticismo da paisagem africana devia ser administrado em pequenas doses, para acicatar o interesse (e o espírito de aventura) dos observadores; para evitar que se transformasse em fator de medo, entravam 
em cena as ilustrações que demonstravam a transformação tecnológica, a domesticação da natureza e a europeização do território.

Em suma, procurava-se passar a imagem de África como um país excêntrico, mas apto para acolher os europeus, que nele podiam encontrar todas as comodidades de que usufruíam na Europa e assim desenvolver normalmente as suas atividades, contrariando, portanto, as representações anteriores dum continente inóspito (Martins, 2014, p.143).

\section{A relação com o Outro}

O exotismo de África era igualmente evidenciado por meio de imagens dos seus habitantes, se bem que a interação com os nativos era bem mais complexa e ilustra adicionais comportamentos de dominação, discriminatórios e até racistas. A fotografia produzia uma figura que tornava essas pessoas em objetos de exposição e consequentemente os racializava (Armstrong, 1999, p.108).

Além do exotismo, as fotos de grupos de negros procuravam mostrar o seu caráter tido como primitivo e selvagem, em contraste com o estilo de vida europeu (Figura 13), aproveitando-se não só da alegada objetividade da fotografia, mas também do fato de a técnica fotográfica ser considerada um instrumento científico ao serviço da antropologia e etnografia (Rocha, Matos, 2019, p.167-172).

Essa perceção fundamentou o estabelecimento duma hierarquia civilizacional que fazia a distinção entre os europeus "civilizados" e os africanos "selvagens". Algumas imagens reforçam essa conceção ao colocar no mesmo plano brancos e negros, os primeiros trajados à europeia e em poses régias e elegantes, os segundos, com trapos e em posturas assustadiças e submissas (Figuras 1 e 14). A tecnologia era outro elemento iconográfico que acentuava aquela diferença. Os brancos eram quem a dominava; os negros olhavam para ela com reverência e espanto (Figuras 8 e 15). Tudo isso reforçava a justificação de missões "civilizadoras" em África e, em geral, a própria ideologia colonial (Halpern, 2018, p.189).

Dentro dessa missão "civilizadora", destacava-se um aspeto em particular: o trabalho. Entendia-se que por meio do trabalho (mesmo que imposto de forma forçada), os nativos, que por natureza não tinham necessidade de trabalhar, seriam educados para fora da percecionada barbárie em que viviam. Adicionalmente, os negros venceriam um salário, com o qual se argumentava que ganhariam gosto pela posse, pelo valor da propriedade, adotariam o sistema económico vigente na Europa e assim poderiam aproveitar mais eficazmente os recursos dos seus territórios. Naturalmente que por debaixo dessa retórica se escondia uma visão utilitária, qual era a de aproveitar uma mão de obra abundante e barata para a construção de obras públicas em África (Jerónimo, 2015, p.39-42, 85-92).

A fotografia não podia deixar de captar esses esforços "civilizadores". Todos os álbuns incluem imagens de negros trabalhando na construção de obras públicas (nomeadamente caminhos de ferro), desempenhando tarefas simples, eminentemente físicas (Figura 14). Em algumas ocasiões, os nativos, nos seus afazeres, eram retratados juntamente com zeladores brancos que observavam o trabalho ou simplesmente posavam para a câmara. A fotografia, na sua alegada objetividade, testemunhava a ação "civilizadora" da presença e da tecnologia europeia. Ironicamente, enquanto mostrava, escondia dos observadores as 
relações de trabalho forçado que se estabeleciam (cf. Landau, 2002, p.161). Aqui, importa referir que fotos retratando trabalhos de construção nos caminhos de ferro de Portugal continental são raras. Queda claro que a missão "civilizacional" e a "lição do trabalho" só deveriam ser aplicadas aos negros. Os europeus já delas não careciam.

Noutro plano, a "civilização" dos africanos era atestada por demonstrações gráficas da sua europeização, retratando-os em trajes, poses ou funções normalmente atribuídas aos europeus (Figura 16). Replicava-se assim junto dos nativos o processo transformativo que vinha sendo aplicado à paisagem. No fundo, tudo contribuía para a construção e publicitação duma relação desigual de poder em que os europeus dominavam os africanos, assente em alguns preconceitos e ideias feitas que ainda hoje perduram (como a preguiça, ou falta de inteligência para desempenhar outros cargos que não os mais físicos).

\section{Considerações finais}

A presença portuguesa em África esteve envolta e deu azo à produção de diversos mitos. Desde logo, como referi, existiam os mitos da herança sagrada e do El Dorado, que faziam das colónias portuguesas partes inalienáveis do Império, que lhe haveriam de fornecer valiosíssimos recursos. Ao longo do século XIX e na entrada para o século XX, foram surgindo outros mitos, associados às ideias de capital e império e aos quais a fotografia deu uma visualidade concreta, reforçando-os. Não olvidemos que essas fotos circularam por muitas mãos e pela própria imprensa ilustrada portuguesa da época, o que contribuiu para o fortalecimento de ideologias comuns entre grupos (cf. Beegan, 2008, p.21-24; Martins, 2014). A análise das fotografias selecionadas neste artigo aponta nessa mesma direção, embora conclusões mais assertivas careçam de estudo adicional, incluindo um corpus documental maior, bem como a comparação com a componente escrita da cultura que produziu aquelas imagens.

Talvez o mito mais imediato seja o do "progresso", segundo o qual a felicidade dos povos assentava na implementação de grandes sistemas tecnocientíficos que acelerariam a circulação de capital, pessoas e bens e facilitariam a exploração de África - o crescimento económico intimamente aliado ao sublime técnico como leitmotivs do "progresso" e sinais de "civilização".

Associado a esse, e ligado também ao movimento oitocentista da partilha do continente africano, temos o mito de África como ausência de "civilização", educação e ordem, que urgia "civilizar", educar e ordenar. Nesse, bem como no mito do Eldorado, a agência recaía sobre o homem europeu, nomeadamente sobre o engenheiro, que assim se revestia de um dever não só para com os seus compatriotas, mas também para com os nativos de África.

Criava-se assim o outro mito de que o sistema europeu, em nível económico e laboral (a necessidade de ter um trabalho e um salário, para adquirir bens), era o único admissível e, portanto, deveria ser universal. Daí a transformação do trabalho forçado em África como algo salutar, que iria beneficiar os negros, também mitificados em criaturas exóticas, mas estultas e indolentes, das quais não se deveria esperar mais que força bruta. Tudo isso apontava para um mito final da benignidade do imperialismo e do colonialismo (nesse caso, português, mas não só), como um processo que beneficiaria os interesses de todos - e que a fotografia mostrava visualmente aos portugueses da metrópole. 
A força desses mitos fica atestada pela sua durabilidade no tempo. Muitas das representações sobre os negros perduram atualmente nas representações racistas que sobre eles ainda recaem. A benquerença do colonialismo transmutou-se na teoria lusotropicalista de Gilberto Freyre, que ainda hoje tem adeptos. Na semana em que inicio este artigo, José Ribeiro e Castro (5 mar. 2020), antigo deputado e ex-líder do partido português Centro Democrático e Social - Partido Popular (CDS-PP), define-se, num texto de opinião, "assumido seguidor" daquele modelo, o qual considera "uma das descobertas mais geniais no domínio das ciências sociais", por vincular os portugueses "a construir uma sociedade não racista". Esses considerandos escapam à temática deste artigo, mas importam por demonstrar a resistência dos mitos criados em torno do colonialismo português, para a qual muito contribuiu a fotografia por conceder uma materialidade visual (que a cultura escrita não conseguia fazer) e, simultânea e dissimuladamente, um caráter objetivo, verdadeiro e até científico às imagens que (nesse caso) empresas coloniais, com uma agenda muito própria, criaram. Este estudo, ainda que limitado pelas razões já aduzidas, contribui para essa teoria e chama a atenção para a pertinência de incluir fotografia nos estudos sobre a história do colonialismo português e as suas ramificações no presente.

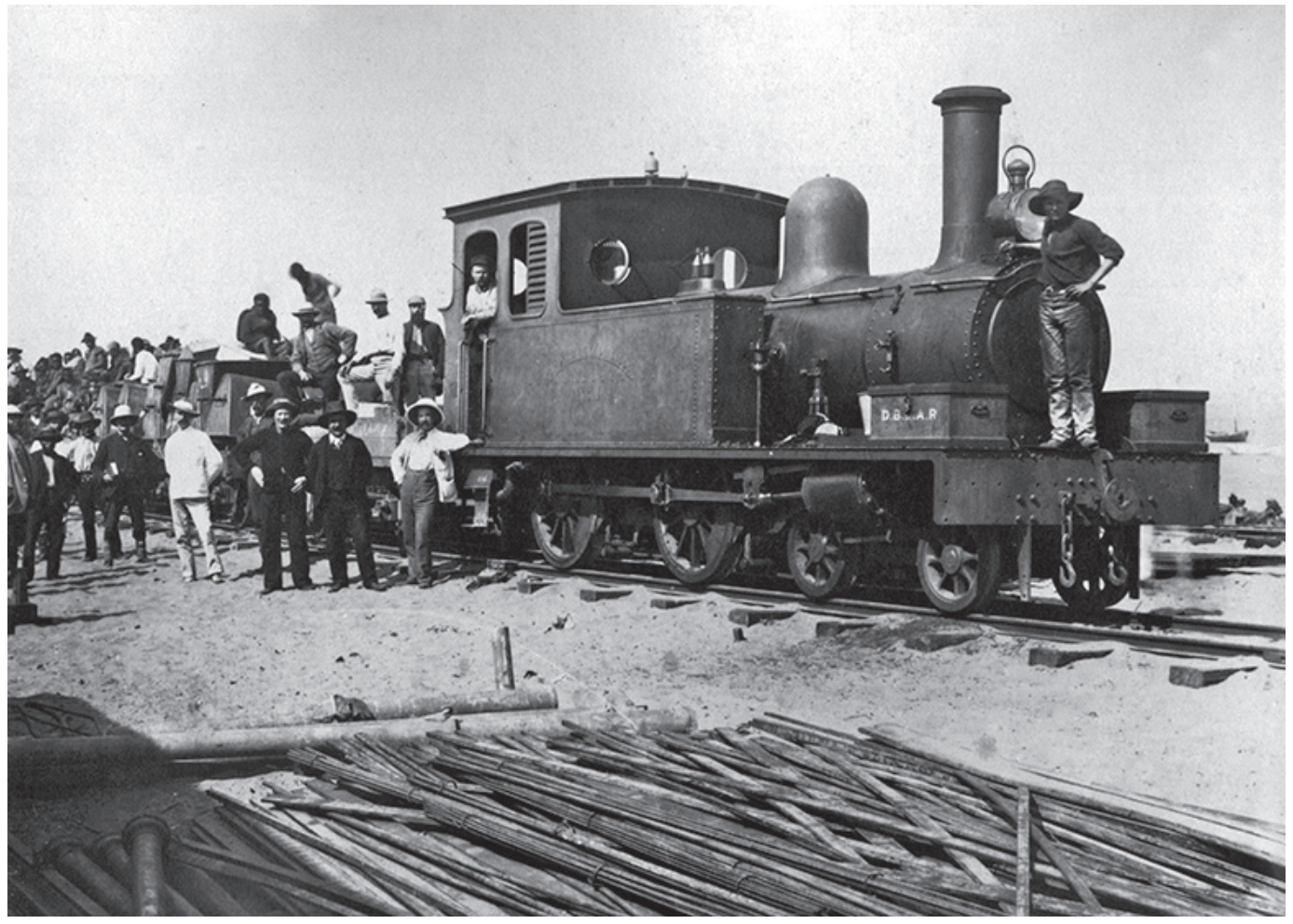

Figura 1: Uma locomotiva da Delagoa Bay \& East African Railway Company, acompanhada do staff técnico e de alguns trabalhadores nativos (Fonte: Views..., c.1887) 


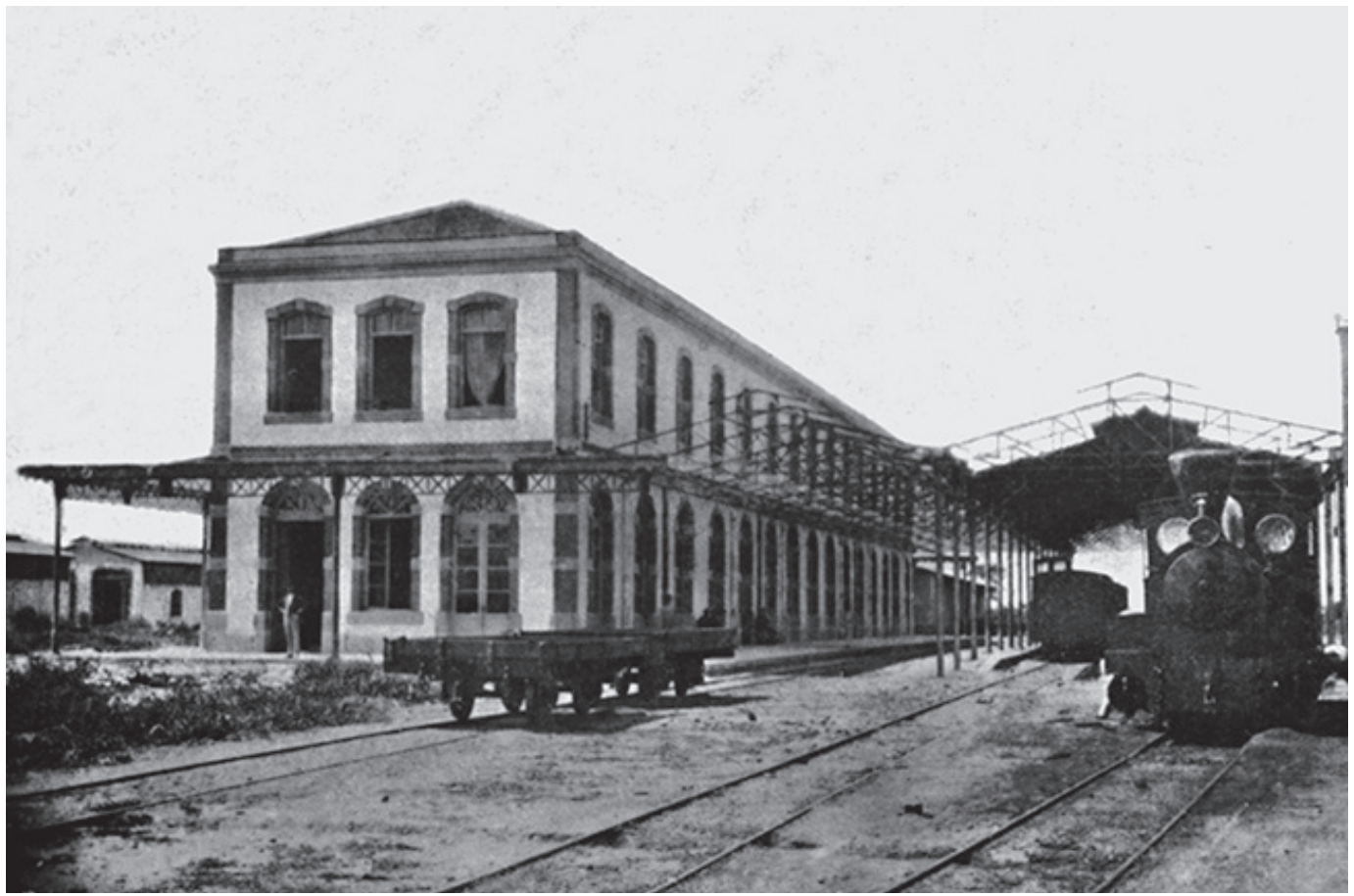

Figura 2: Locomotiva e vagões na gare da estação de Luanda; legenda original: “Estação Principal de Loanda” (Fonte: Memória..., 1909)

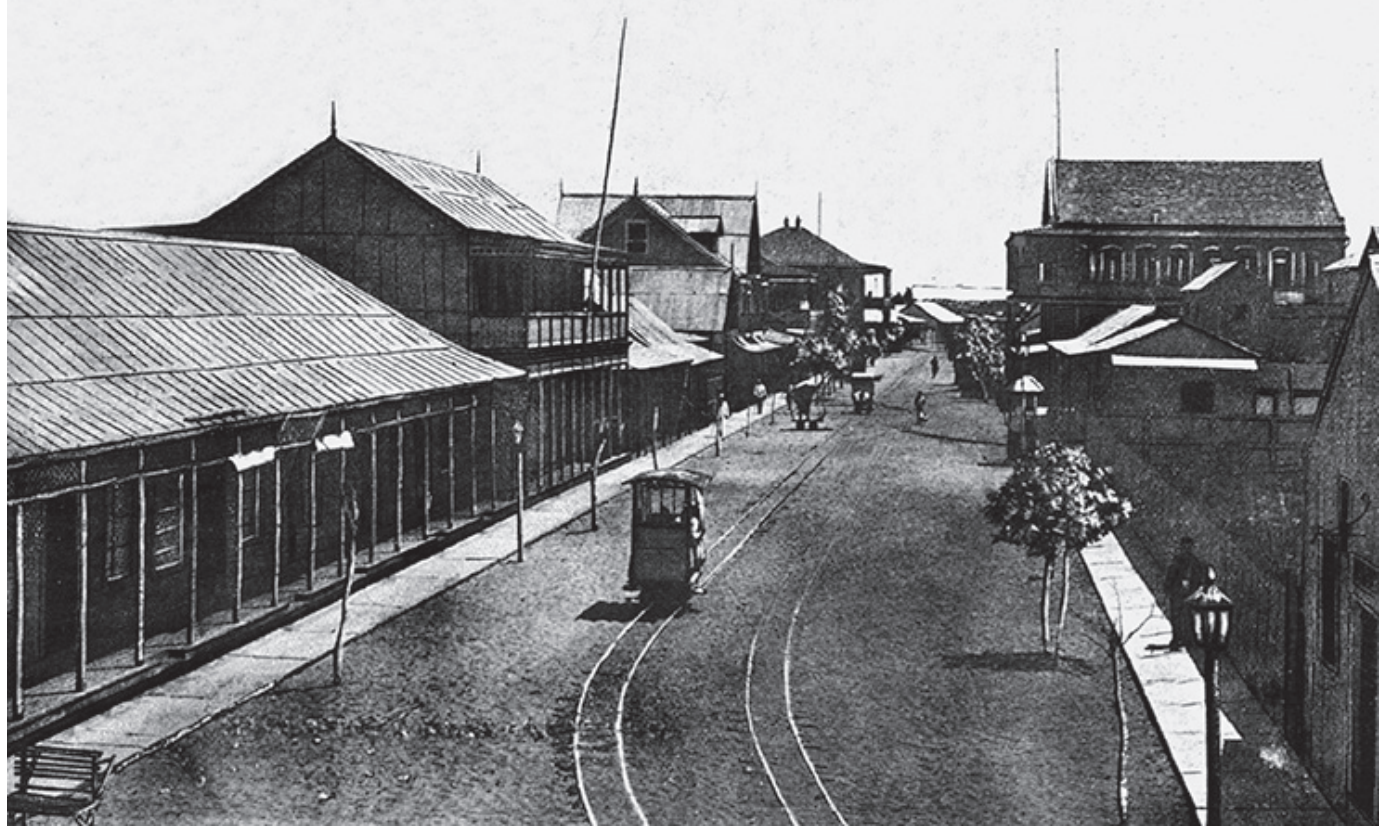

Figura 3: Panorâmica da rua Valsassina, na Beira, com um tramway e diversos edifícios; legenda original: “Beira - Rua Valsassina" (Fonte: Território..., 1902) 


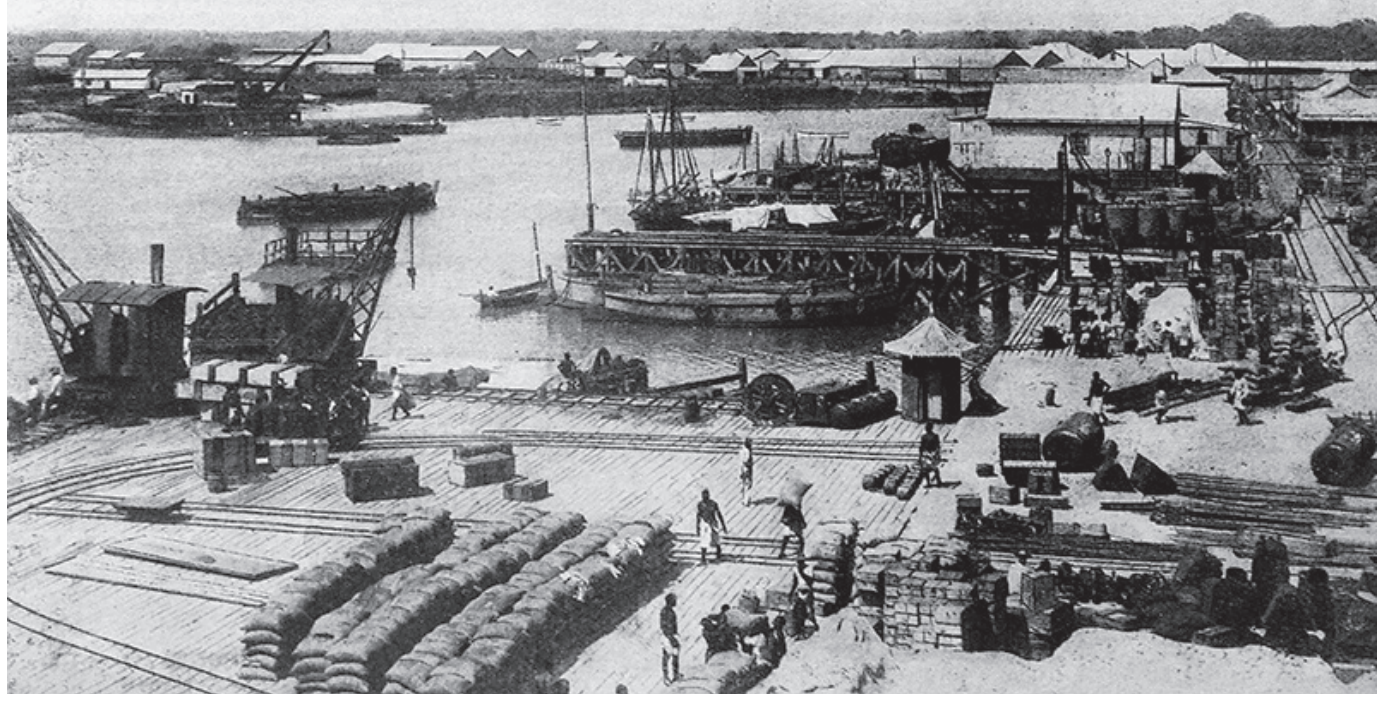

Figura 4: Panorâmica do porto da Beira, incluindo cais, linhas de acesso e diversos trabalhadores; legenda original: "O porto em 1904" (Fonte: Quarenta..., 1934)

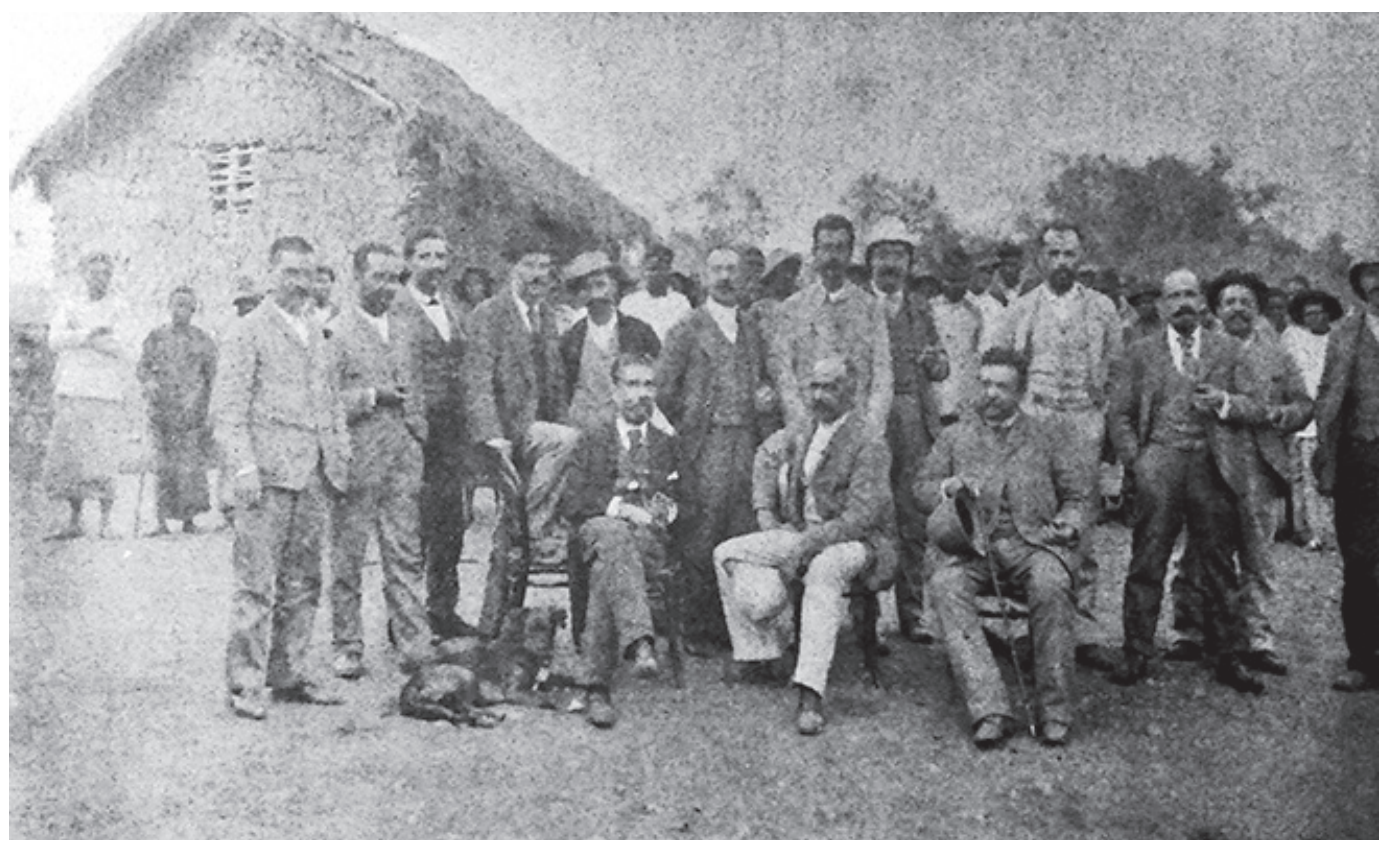

Figura 5: Diverso pessoal empregado na construção da linha de Ambaca; legenda original: "Pessoal da linha, n'um acampamento. Visita do Governador" (Fonte: Miscelânea..., c.1894) 


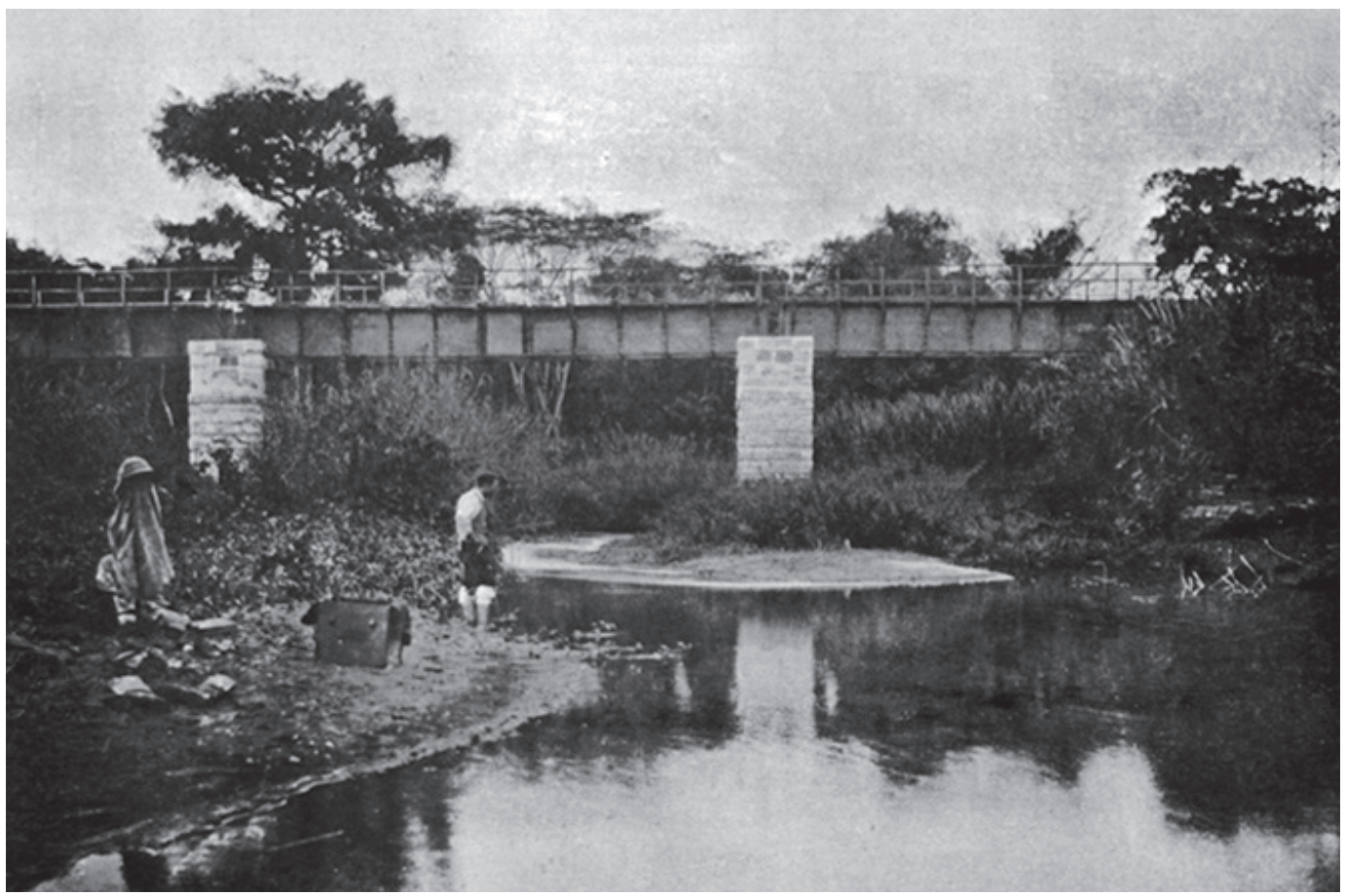

Figura 6: Técnico e ponte da linha de Ambaca sobre o rio Luinha; legenda original: "Ponte do Luinha” (Fonte: Memória..., 1909)

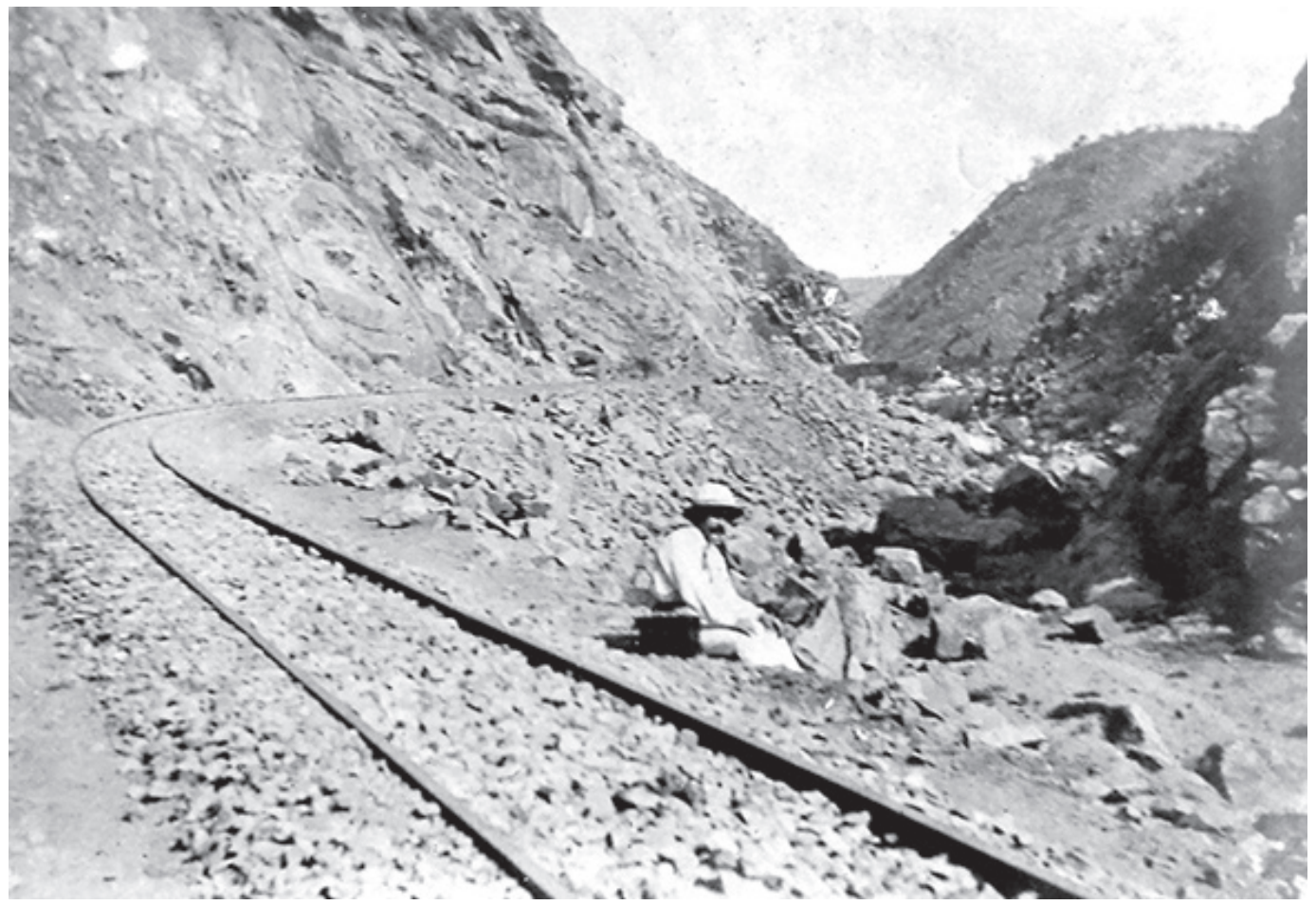

Figura 7: Engenheiro sentado na linha de Benguela à passagem em Lengue; legenda original: "Finished line in Lengue, viaduct no. 1 in distance. June 1906" (Fonte: Benguela Railway, c.1906) 


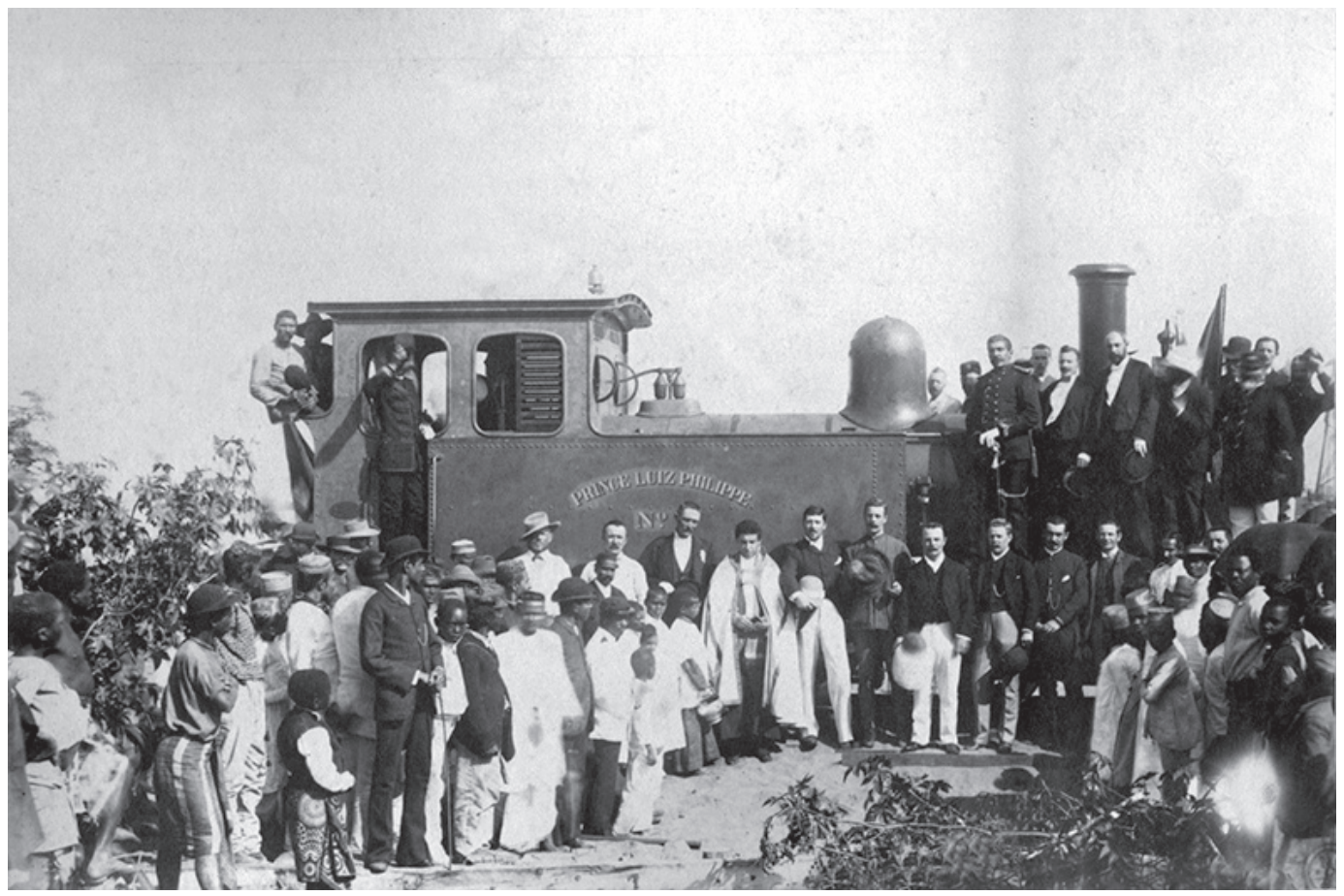

Figura 8: Inauguração da linha de Lourenço Marques (Fonte: Views..., c.1887)

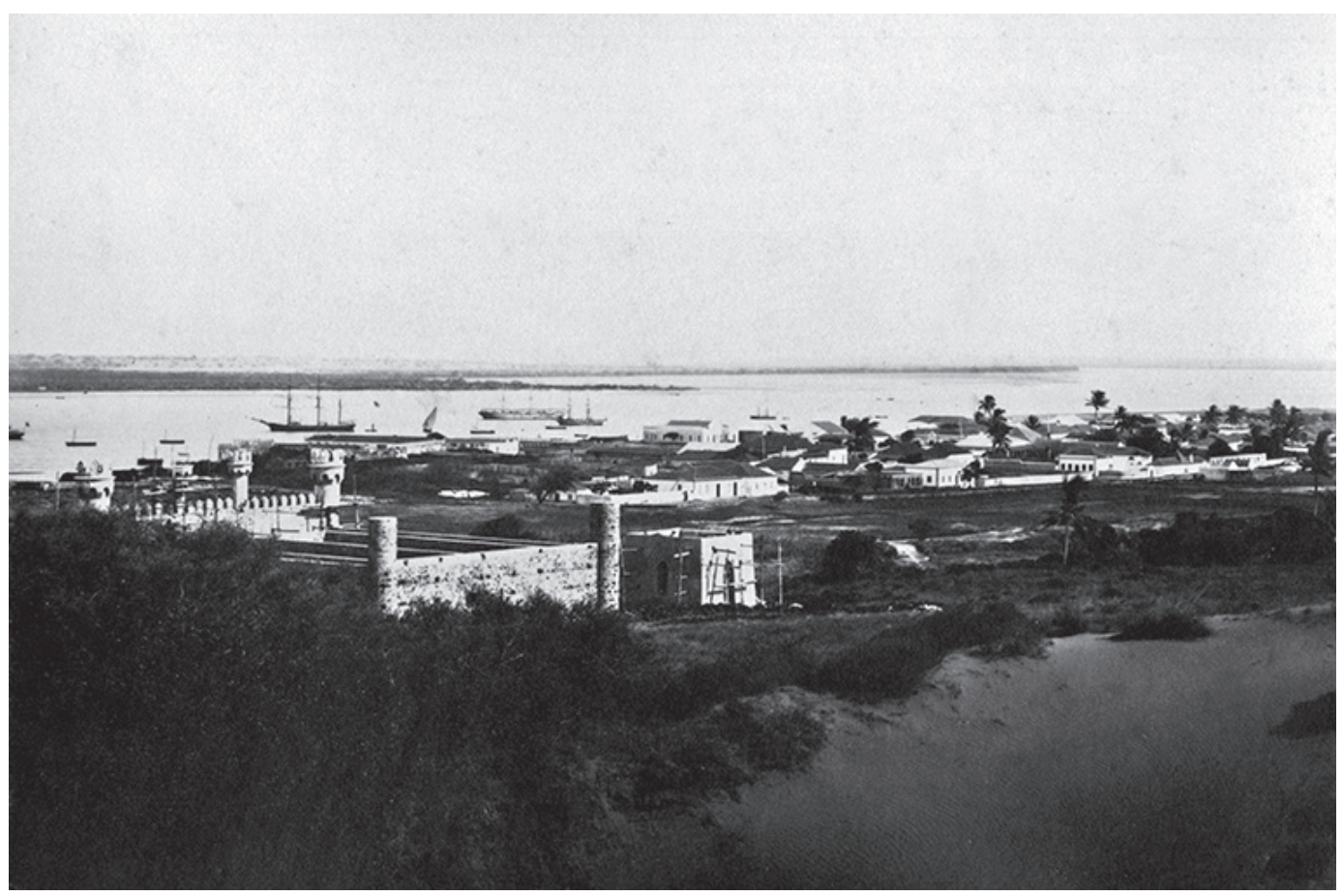

Figura 9: Panorâmica de Lourenço Marques e da baía circundante (Fonte: Views..., c.1887) 


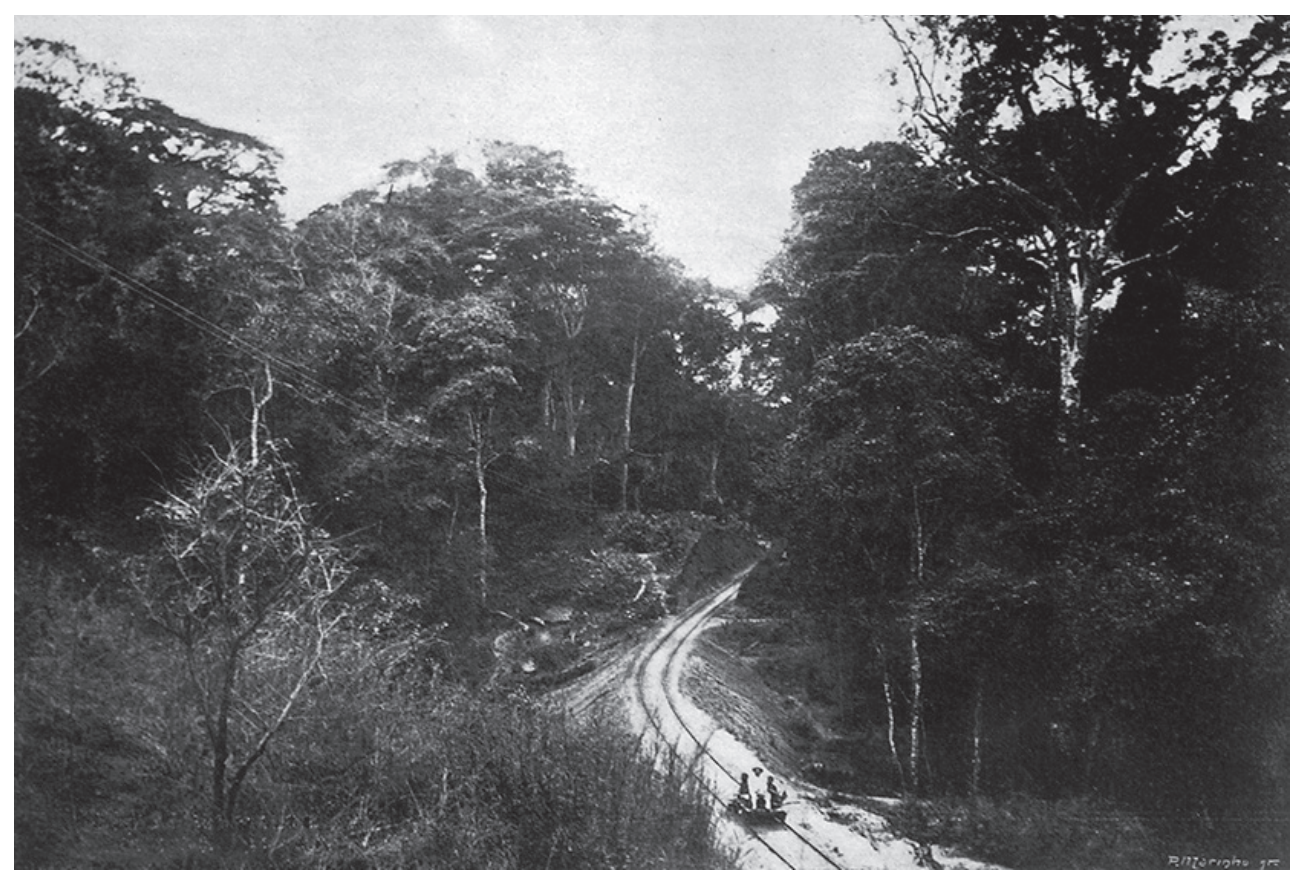

Figura 10: "Dresine” de inspeção na linha da Beira, atravessando a floreta de Amatongas; legenda original: "Amatongas - Floresta - Caminho de ferro" (Fonte: Território..., 1902)

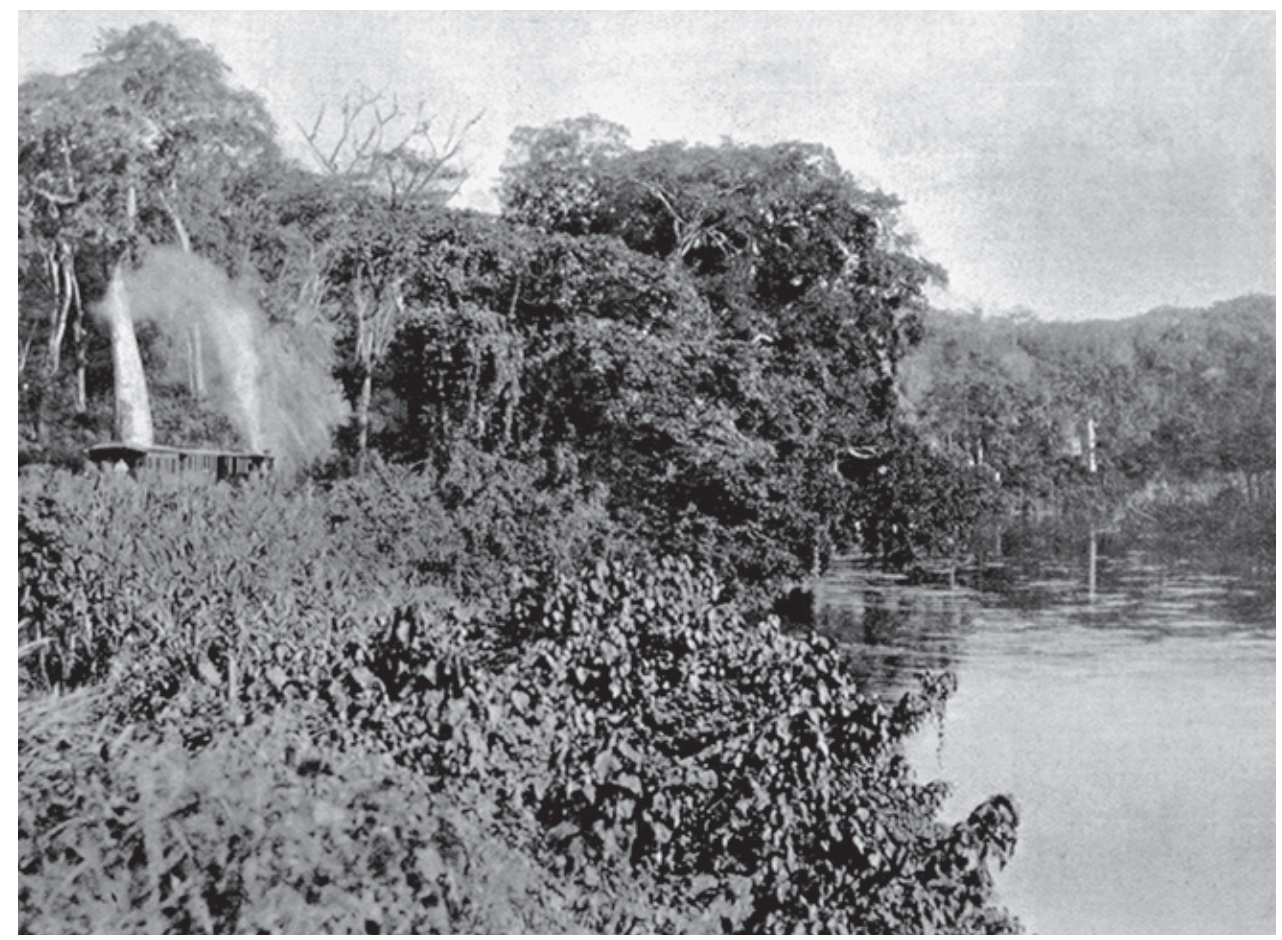

Figura 11: Comboio viajando na linha de Ambaca junto ao rio Lucala; legenda original: "Margens do rio Lucalla, k[m] 225" (Fonte: Memória..., 1909) 


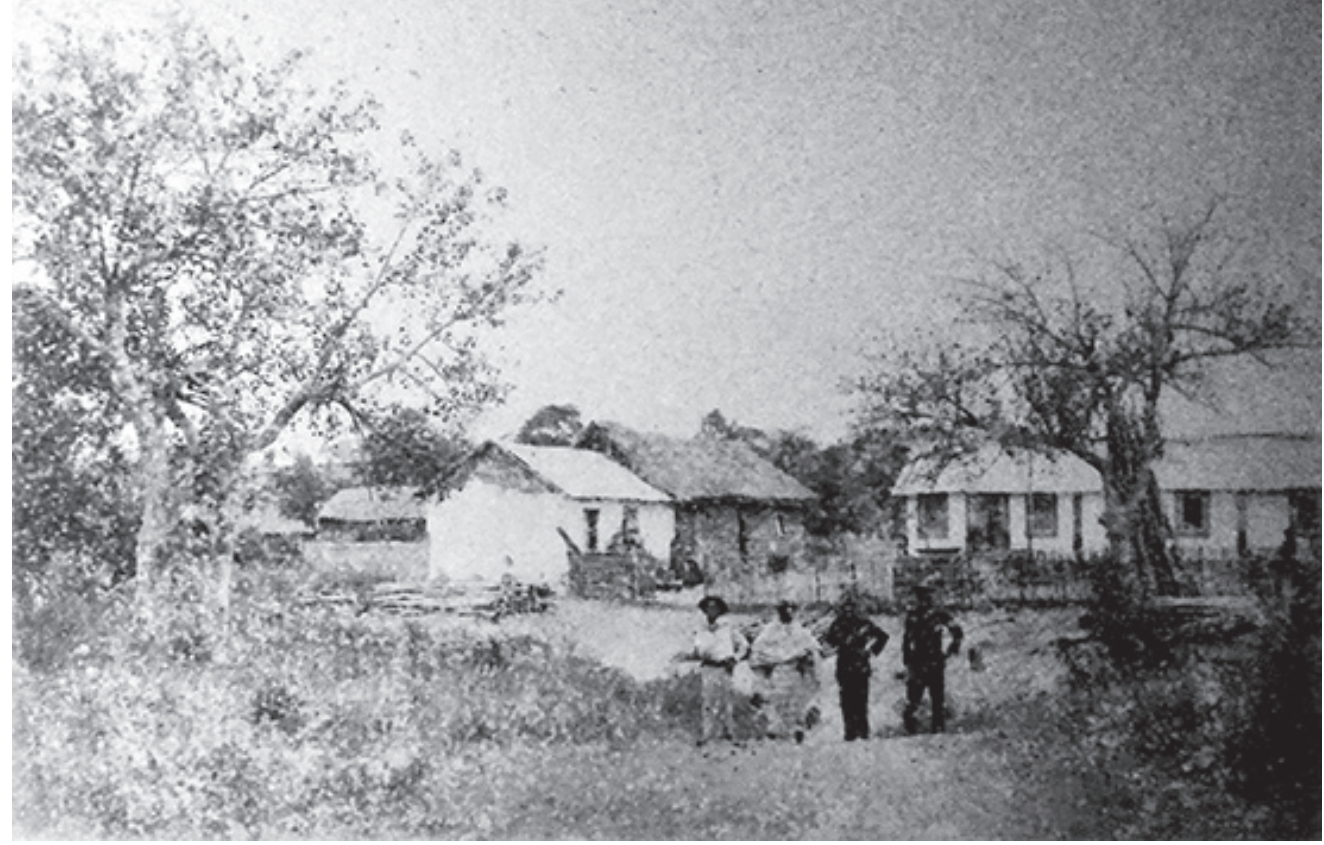

Figura 12: Povoado de Cassoneca, nas imediações da linha de Ambaca; legenda original: "Aldêa de Cassoneca k[m] 140" (Fonte: Miscelânea..., c.1894)

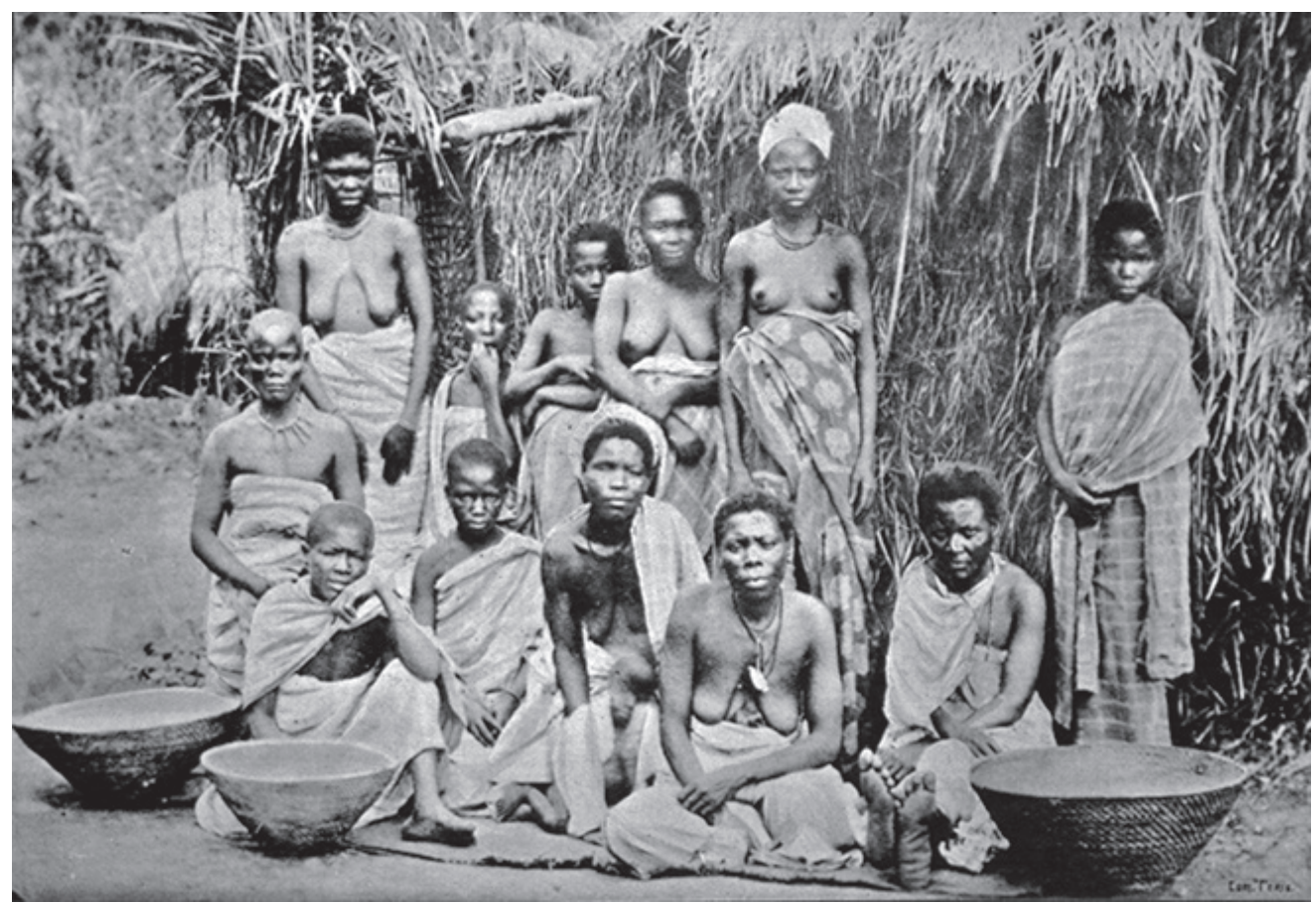

Figura 13: Mulheres angolanas; legenda original: "Grupo de quitandeiras [vendedeiras]" (Fonte: Memória..., 1909) 


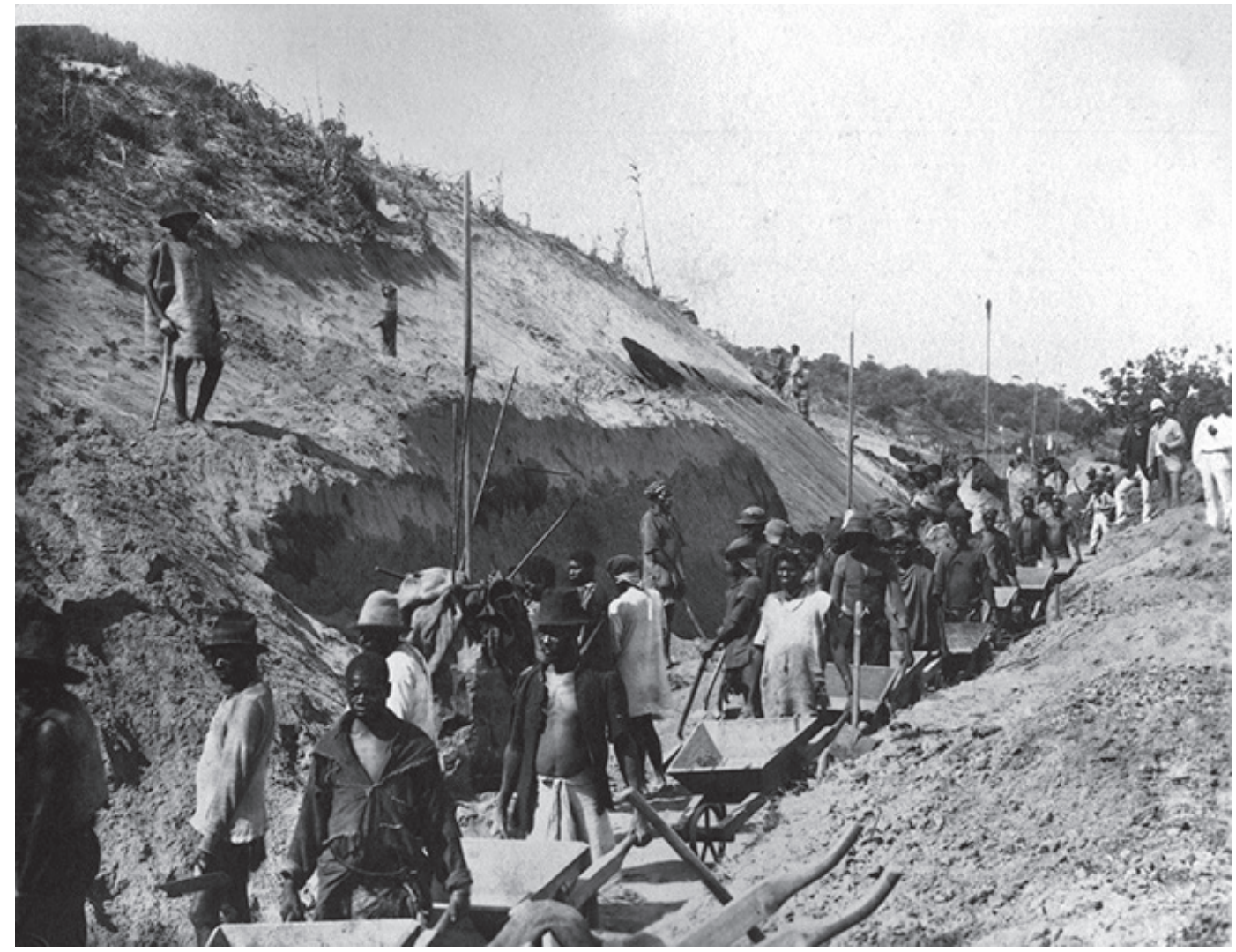

Figura 14: Trabalhadores nativos abrindo uma trincheira para a linha de Lourenço Marques (Fonte: Views..., c.1887) 


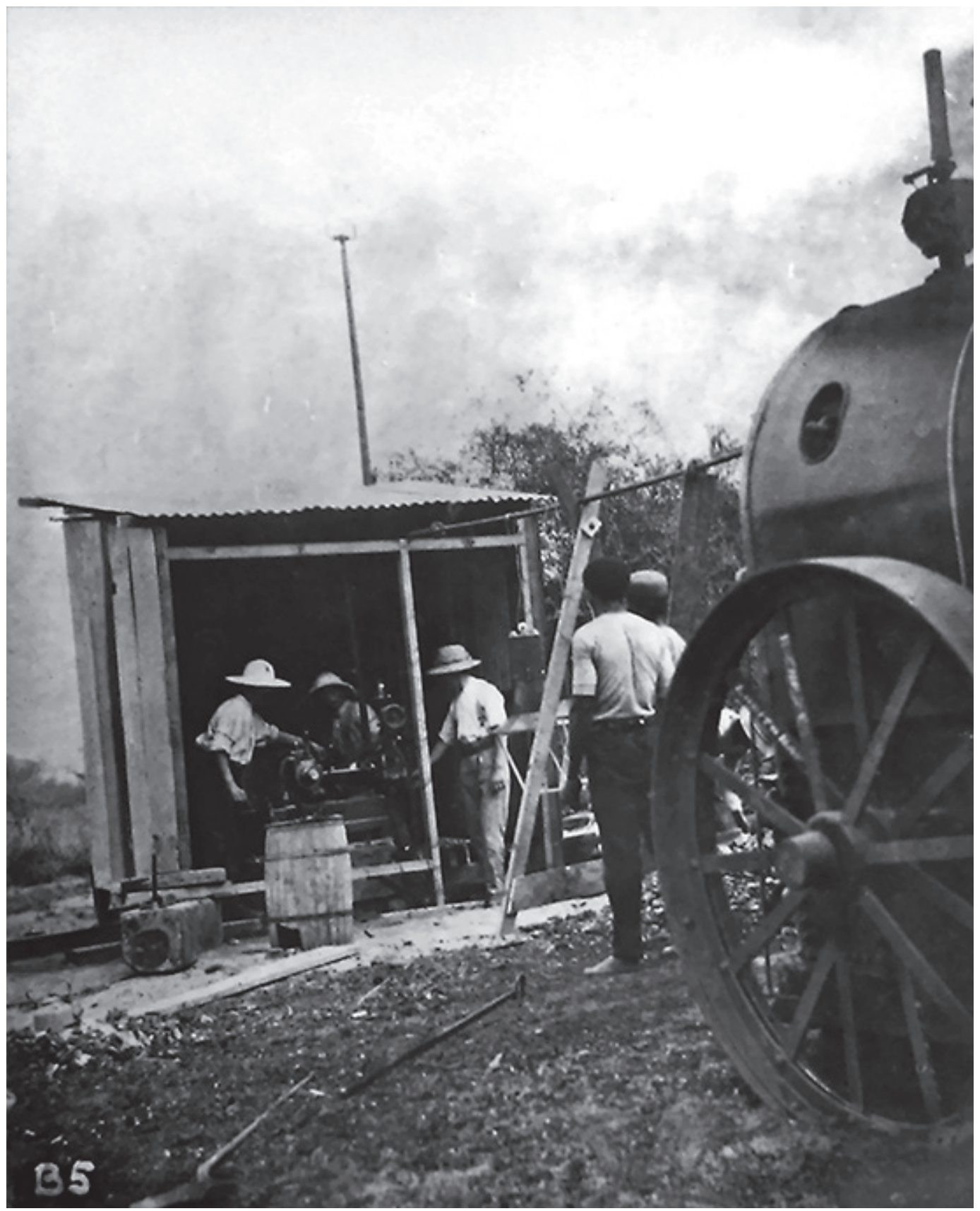

Figura 15: Trabalhadores nativos observando os operadores dum dínamo, na construção da linha de Benguela; legenda original: "Dynamo Section no. 5. December, 1905" (Fonte: Benguela Railway, c.1906) 


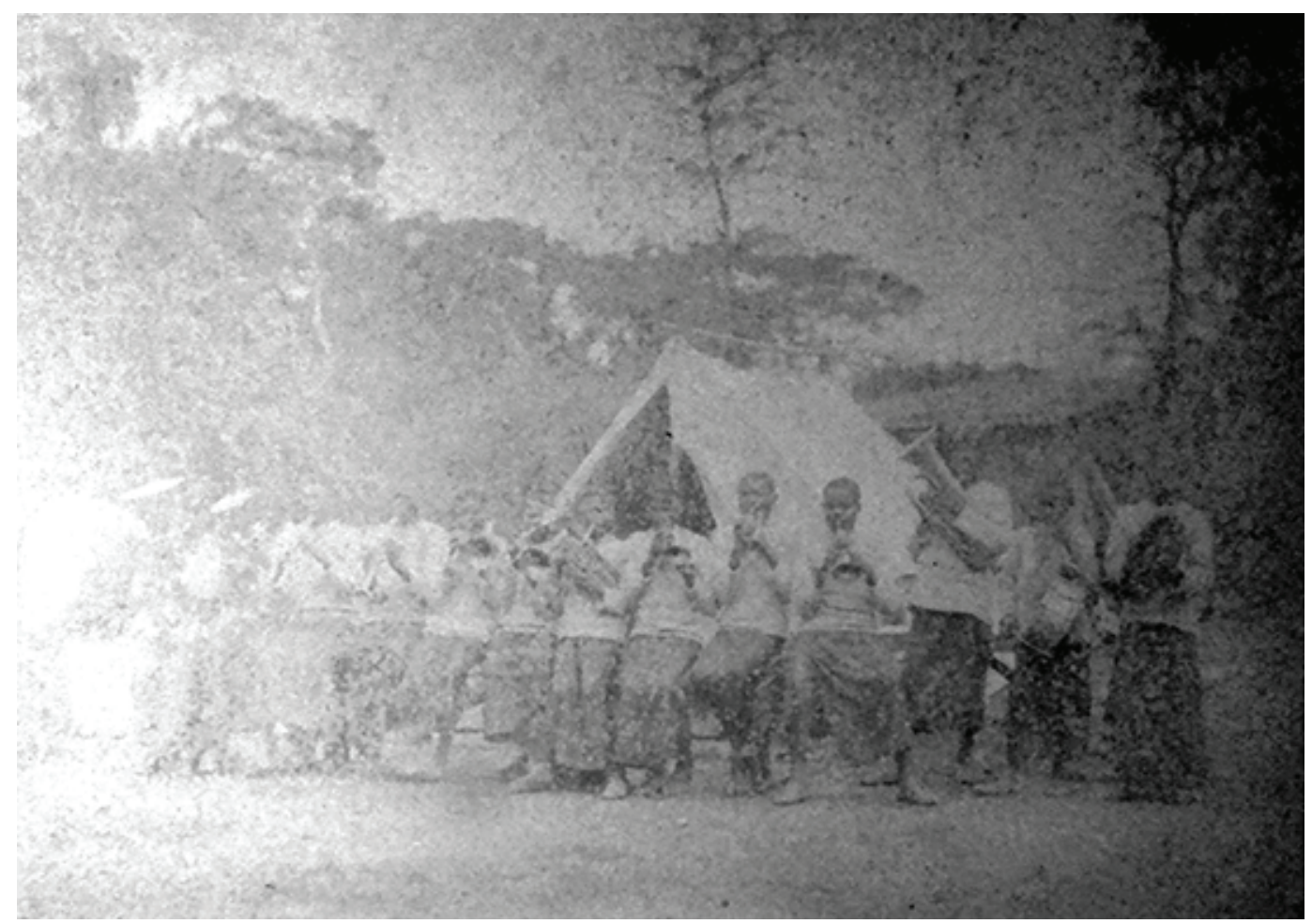

Figura 16: Banda musical de crianças negras; legenda original: “Charanga de pretos na Fazenda Hócco [Km 287]” (Fonte: Miscelânea..., c.1894)

\section{AGRADECIMENTOS}

Gostaria de agradecer o apoio institucional e académico fornecido pelo Centro Interuniversitário de História das Ciências e da Tecnologia da NOVA School of Science and Technology e pelo Department of History da University of York, bem como o suporte financeiro da Fundação para a Ciência e Tecnologia (bolsa de pós-doutoramento SFRH/BPD/95212/2013 e moldura legal criada pelo decreto-lei n.57/2016 e pela lei n.57/2017).

\section{NOTAS}

${ }^{1}$ A Companhia Real dos Caminhos de Ferro Através d'África foi fundada em 1886 para construir e operar a linha-férrea de Luanda a Ambaca (inaugurada na sua totalidade em 1899). A Companhia do Caminho de Ferro de Benguela foi criada em 1902 para assentar e explorar a ferrovia desde aquela cidade costeira à fronteira com o Congo, a qual inaugurou em 1929. Já a Delagoa Bay \& East African Company foi encarregue em 1887 de concluir o caminho de ferro entre Lourenço Marques (atual Maputo) e a fronteira com o Transvaal (Navarro, 2018).

${ }^{2}$ A satisfação advinda do vislumbre duma máquina em operação, alegoria última do engenho intelectual e tecnológico humano (Kasson, 1976, p.162-180).

${ }^{3}$ Uma fotografia da Companhia de Moçambique retrata também membros duma expedição científica (Quarenta..., 1934).

${ }^{4}$ Existem também fotografias retratando os peritos europeus em momentos de lazer, mas apenas em Benguela Railway (c.1906). 


\section{REFERÊNCIAS}

ADAS, Michael. Machines as the measure of men: science, technology, and ideologies of Western dominance. Ithaca: Cornell University Press, 1989.

ALEXANDRE, Valentim. Velho Brasil, novas Áfricas: Portugal e o Império, 1808-1975. Porto: Afrontamento, 2000.

ARMSTRONG, Nancy. Fiction in the age of photography: the legacy of British Realism. Cambridge, MA: Harvard University Press, 1999.

BARTHES, Roland. Mythologies. New York: The Noonday Press, 1972.

BEEGAN, Gerry. The mass image: a social history of photomechanical reproduction in Victorian London. Basingstoke: Palgrave Macmillan, 2008.

BENGUEla RAILWAY. Angola, Portuguese West Africa: wiews showing progress of work from November 1904 to June 1906. [S.1.: s.n.], c.1906.

CASTRO, José Ribeiro e. Racismo e lusotropicalismo. Observador, 5 mar. 2020. Disponível em: https://observador.pt/opiniao/ racismo-e-luso-tropicalismo. Acesso em: 7 mar. 2020.

DAVIS, Clarence B.; WILBURN Jr., Kenneth E.; ROBINSON, Ronald E. Railway Imperialism. London: Greenwood Press, 1991.

DIOGO, Maria Paula. Domesticating the wilderness: Portuguese engineering and the occupation of Africa. In: Matos, Ana Cardoso et al. (ed.). The quest for a professional identity: engineers between training and action. Lisboa: Colibri, 2009. p.471-482.

DUBOIS, Philippe. O ato fotográfico. Lisboa: Vega, 1992.

FERNANDES, Paulo Jorge. A fotografia e a edificação do Estado colonial: a missão de Mariano de Carvalho à província de Moçambique em 1890. In: Vicente, Filipa Lowndes (ed.). O império da visão: fotografia no contexto colonial português, 1860-1960. Lisboa: Edições 70, 2014. p.195-210.

FLICK, Uwe. An introduction to qualitative research. London: Sage, 2003.

FORTIER-KRIEGEL, Anne. Les "grands sites" créés par les ouvrages d'art ferroviaires. Revue d'Histoire des Chemins de Fer, n.32-33, p.93-100, 2005.

FOSTER, Jeremy. Capturing and losing the "Lie of the Land": railway photography and colonial nationalism in early twentiethcentury South Africa. In: Schwartz, Joan M.;
Ryan, James R. (ed.). Picturing place: photography and the geographical information. New York: I.B. Tauris, 2003. p.141-161.

FRANKLIN, Margery B.; BECKLEN, Robert C.; DOYLE, Charlotte L. The influence of titles on how paintings are seen. Leonardo: Journal of the International Society for the Arts, Sciences and Technology, v.26, n.2, p.103-108, 1993.

FREUND, Gisèle. Fotografia e sociedade. Lisboa: Vega, 1995.

GILMARTIN, Mary. Colonialism/Imperialism. In: Gallaher, Carolyn et al. (ed.). Key concepts in political geography. London: Sage, 2009. p.115-123.

HALPERN, Rick. The back of the photograph: making meaning in the archives. Radical History Review, n.132, p.187-199, 2018.

HEADRICK, Daniel R. The tools of empire: technology and European imperialism in the nineteenth century. Oxford: Oxford University Press, 1981.

HEINTZE, Beatrix. In pursuit of a chameleon: early ethnographic photography from Angola in context. History in Africa, v.17, p.131-156, 1990.

JERÓNIMO, Miguel Bandeira. The "civilising mission" of Portuguese colonialism, 1870-1930. Basingstoke: Palgrave Macmillan, 2015.

KASSON, John F. Civilizing the machine: technology and republican values in America, 17761900. New York: Grossman, 1976.

LAINS, Pedro. Causas do colonialismo português em África, 1822-1975. Análise Social, v.33, n.146147/2-3, p.463-496, 1998.

LANDAU, Paul S. Empires of the visual: photography and colonial administration in Africa. In: Landau, Paul S.; Kaspin, Deborah D. (ed.). Images and empires: visuality in colonial and postcolonial Africa. Berkeley, CA: University of California Press, 2002. p.141-171.

MARTINS, Leonor Pires. Um império de papel: imagens do colonialismo português na imprensa periódica ilustrada. Lisboa: Ediçõos 70, 2014.

MATOS, Ana Cardoso de. Os testemunhos fotográficos da obra pública em Portugal. In: Aguilar, Inmaculada; Doménech, Sergi (ed.). Fotografía y obra pública. Valencia: Conselleria d'Infraestructures, Territori i Medi Ambient, 2014. p.11-29.

MEMÓRIA explicativa e justificativa dos atos e da situação da Companhia Real dos Caminhos de Ferro Através d'África. Porto: Oficinas do Comércio do Porto, 1909. 
MISCELÂNEA Caminho de Ferro de Loanda a Ambaca, maço 756-A 1I (Arquivo Histórico Ultramarino, Lisboa), c.1894.

NAVARRO, Bruno J. Um império projetado pelo "silvo da locomotiva": o papel da engenharia portuguesa na apropriação do espaço colonial africano: Angola e Moçambique, 1869-1930. Lisboa: Colibri, 2018.

NYE, David E. American technological sublime. Cambridge, MA: The MIT Press, 1999.

OLIVEIRA, Eduardo Romero. Photographic views of railroads: recording public works in nineteenth century Brazil. História, Ciências, Saúde-Manguinhos, v.25, n.3, p.695-723, 2018.

QUARENTA anos de administração no território de Manica e Sofala. [S.1.: s.n.], 1934.

ROCHA, Liliana Oliveira da; MATOS, Patrícia Ferraz. Fotografias de Angola do século XIX: o "Álbum fotográfico-literário" de Cunha Moraes. Tempos e Espaços em Educação, v.12, n.31, p.165186, 2019.
RYAN, James R. Picturing empire: photography and the visualization of the British Empire. Chicago: The University of Chicago Press, 1997.

SOUSA, Jorge Pedro. Subsídio para o estudo das origens do jornalismo iconográfico em Portugal: revistas ilustradas, gravura e fotografia (18351914). In: Barros, Teresa Antas de et al. (ed.). Ciências da comunicação: vinte anos de investigação em Portugal. Viseu: Sopcom; Instituto Politécnico de Viseu, 2017. p.574-599.

TERRITÓRIO de Manica e Sofala e a administração da Companhia de Moçambique (1892-1900). Monografia para ser presente ao Congresso Colonial promovido pela Sociedade de Geografia de Lisboa em 1901. Lisboa: Tipografia da Companhia Nacional Editora, 1902.

VICENTE, Filipa Lowndes. O império da visão: histórias de um livro. In: Vicente, Filipa Lowndes (Ed.). O império da visão: fotografia no contexto colonial português, 1860-1960. Lisboa: Edições 70, 2014. p.11-30.

VIEWS of Lourenço Marques (Delagoa Bay) and Transvaal Railway. [S.1.: s.n.], c.1887.

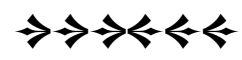

